\title{
REFLECTIONS OF A TRAUMA COUNSELLOR: THEORY MEETS PRACTICE
}

\section{Fatima Williams}

\section{INTRODUCTION}

I worked at The Trauma Centre for Survivors of Violence and Torture, which is based in Cape Town, from 2001 until 2007, first as a counsellor and then as a team leader. The organisation often receives requests from business companies to do debriefing sessions after these companies had experienced a traumatic incident.

Critical Stress Incident Debriefing (CSID) has its origins in the military, where it was used to assist soldiers who had undergone traumatic experiences (Mitchell \& Everly, 1997). It is based on the assumption that early treatment prevents the development of a psychiatric disorder and that the best time to do a debriefing is within 24-72 hours after the traumatic event (Scrignar, 1996). Debriefing has been a controversial issue, with some authors stating that it is not helpful (Appelt, 2003 cites eleven studies to support this view; Bass \& Davis, 2002; Crossley, 2000; Giarratano, 2004 and others argue that it is beneficial; Hajiyannis \& Robertson, 1999; Raphael \& Meldrum, 1995; Rynearson, 2001; Stacey, 1999). The Trauma Centre uses "crisis counselling" as a model rather than debriefing in its true form (Stacey, 1999). This article will provide an illustration of the process of crisis counselling.

My role as team leader involved co-ordinating off-site group crisis counselling sessions and arranging for counsellors to go and conduct these sessions off-site. In the first five years of working at The Trauma Centre I had arranged and facilitated numerous crisis counselling sessions. Retrospectively I realise that I had always facilitated these sessions in a very clinical manner, confident that I had the skills to deal with them and never doubting that I would be able to "hold" the material.

I had become complacent and possibly arrogant in believing that I was prepared to deal with any situation. I decided to write this paper after I co-facilitated a crisis counselling session which impacted on me and really made me reflect on my work and the impact it was having on me. I began to write this as a means of reflecting on my experience, but also hoping that this paper would raise certain questions for people working in the field of trauma management.

\section{A NEW BEGINNING}

Up until recently I had never really engaged with the impact that my work was having on me. Yes, I was aware that over the years I had become more security conscious and that I had changed some of my habits to accommodate my feelings of Cape Town not being a safe place in which to live.

Vicarious trauma was a term that I was theoretically familiar with but, until that fateful day, had never fully understood. McCann and Pearlman (1989) provided a theoretical conceptualisation around the psychological impact on therapists who work with trauma victims, which they referred to as vicarious traumatisation.

Other professions to which they refer include psychotherapists, nurses, doctors, social workers, hospice workers, prison personnel, emergency service personnel, AIDS volunteers, fire fighters, police and prosecutors (Saakvitne \& Pearlman, 1996). Giarratano (2004:260) defines vicarious traumatisation as occurring "when someone hearing about a trauma or helping in the 
aftermath of trauma becomes emotionally affected." She adds that the onset of vicarious trauma can be acute and resolve very suddenly, and that the symptoms resemble those of clients. The author further indicates that these symptoms can arise when:

- The counsellor hears a story that links to issues which make us vulnerable;

- The counsellor is personally involved in some way in the event;

- The counsellor is exhausted;

- When the client's narrative is similar to a distressing issue in the counsellor's life or an unresolved issue from his/her past.

When my colleague approached me to co-ordinate a crisis counselling session in Phillipi, ${ }^{1} \mathrm{I}$ didn't think about the implications and as usual made the necessary arrangements. Without thinking twice, I offered to co-facilitate the session with her. We agreed to go in separate cars because of our other work commitments and, as we set off to the session, I was enjoying the sunshine after many days of rain and didn't give the session much thought because I was going to do the familiar (or so I thought).

We arrived at the venue, which was located in an impoverished area with many people milling around. I was also struck by the noisiness of the area. We went to meet with the manager of the shop and he started telling us that the shop had experienced three armed robberies in one year and that he himself had experienced several armed robberies. He casually told us that he had a gun pointed to his head and a gun thrust into his mouth before. At this point for the first time in my career as a trauma counsellor, I experienced a terror which I had not felt before. My instinct was to run and leave the area immediately. I had this sense of foreboding that my own life could be in danger. I was surprised by the primitive nature of my response and struggled to maintain my composure, whilst at the same trying to understand what was happening to me.

In order to make a diagnosis of Post-Traumatic Stress Disorder (PTSD) various criteria need to be fulfilled (Scrignar, 1996). The DSM IV (1994) defines three clusters of symptoms in PTSD. These include: re-experiencing, avoidance and increased arousal. The discussion of the criteria will highlight the symptoms of responses to trauma, according to the DSM IV (1994:427-429).

\section{Criterion A}

The person has been exposed to a traumatic event in which both of the following were present:

- The person experienced, witnessed or was confronted with an event or events that involved actual or threatened death or serious injury, or a threat to the physical integrity of self or others.

- The person's response involved intense fear, helplessness or horror.

\section{Criterion B}

Victims of trauma often have experiences where they think that the trauma is recurring. It is important for the counsellor to be aware of this because "the re-experiencing cluster is the sine qua non distinguishing PTSD from other anxiety disorders" (Scrignar, 1996:19). This includes flashbacks of the event, illusions, hallucinations and feeling as if the traumatic event is recurring. The internal or external cues can lead to intense psychological or physiological distress, e.g. cramps or headaches.

1 Philippi is a township situated approximately 22 kilometres outside of Cape Town. 


\section{Criterion C}

This includes a persistent avoidance of stimuli associated with the trauma, which aims to reduce the anxiety felt by the person. Unfortunately, often as the anxiety decreases the avoidance can increase, which often leads to further difficulties, e.g. avoidance of work. The traumatised person also presents with symptoms of depression, e.g. a lack of interest in life.

\section{Criterion D}

The victim often experiences problems with insomnia, difficulties with concentration and hyper-vigilance, i.e. being overly aware of what is happening around them.

\section{Criterion E}

In order for PTSD to be diagnosed, symptoms must persist beyond one month of the trauma.

\section{Criterion F}

This extends the diagnosis to include observable impairments in functioning. In PTSD often work relations and social activities are impaired.

Often when we arrived at businesses, we had to wait while employees are gathered and the room is set up for the session and this time was no different. What was different was that I was acutely aware of the noise around me and I felt nauseous. The headache which I had since the morning had become worse. Throughout my time in the store, I was distressed at my inability to make sense of why this time was different from all the previous sessions. I had always prided myself on my self-awareness and now not being able to find answers was terrifying in itself!

\section{THE SESSION}

We eventually started our session and there were three women present. We had three latecomers so we finally had six participants and the session lasted for one hour. The themes that emerged in the session were feelings of not being safe, helplessness and terror at the possibility of another incident. All the members also thought that they were going to die during the incident. The robbers had also come back to the store the next day (as customers) and the group members believed that they had wanted to see if they would be recognised and thus the members feared that the robbers would try to harm them so that they could not identify them.

I have read widely on the responses to traumatic events and on a daily basis I educate clients about these symptoms; however, here I found myself feeling the terror, anxiety, helplessness and, worst of all, trapped. The theoretical concepts came to life and I experienced the intrusive thoughts. During the session I began to worry about how my colleague and I would get out of the shop safely and whether we would be able to return to work unharmed. I had thoughts of being robbed, hijacked and shot. I began to think about my family, what I needed to protect and what I did not want to lose in the event of being robbed outside the shop. As the session progressed it was difficult for me to be present in the session and I felt as if the members were voicing my feelings.

Fortunately my colleague took the lead and I was not expected to be very active in the session. The thought that was uppermost in my mind was that now I truly knew how traumatised clients felt. I was torn between a sense of relief that once the session was over I would leave the situation and a feeling of guilt that the group members had to stay behind. I was also questioning how anybody could work in a situation where they were constantly in danger. I know that this sounds naïve and my thoughts around the effects of constant exposure to trauma were not new, but for me the terror that I felt shed a new light - or shall I say darkness - onto 
my thoughts. I had previously empathised with my clients' terror and now I knew it. The divide between counsellor and client had been breached and I felt like a client who was enacting the role of counsellor.

The session ended and we left; however, I felt in complete turmoil. In my car I realised that something had changed for me and I was left with more questions than answers. As I saw Table Mountain I experienced tremendous relief because I felt that I was safe again.

\section{THE AFTERMATH}

Later I discussed the session and my feelings with a colleague and she raised an interesting point when she said that there is something containing about the co-facilitators travelling in the same car, because then one has a sense of being in the situation together. I have reflected on her statement and I do agree with her, because the counsellors then have the opportunity to share their experience with each other.

Up until this point I had never consciously thought about the fact that crisis counselling sessions occur in places where a traumatic event had occurred and where it could reoccur. This has made me think about clients who live with continuous trauma. The reality is that, if we lived in a country like Norway, we could dismiss the clients' fear of the event recurring as paranoia and as merely a reaction to trauma. The reality in South Africa is that such events can and do reoccur and that we do live in a very unsafe society.

I had lulled myself into thinking that the event was past and never stopped to think what would happen if the event was to recur while I was conducting a session.

During this session I had visualised gunmen bursting into the session and I even prepared what I would do. I experienced what so many clients had spoken about before, where I tried to plan what I would do if the event recurred. Even though I had not been present during the incident, I felt as if it were as alive to me as if it were happening in front of me.

I also realised what an intensely private experience trauma is, because it attacks your very being and the reactions feel as if they are reaching your very core. Again, I had always rationally told clients to share their experiences because it aids recovery. TRAUMA IS NOT RATIONAL and that I learnt that in that small office. I felt embarrassed and ashamed of my reactions, because I am a professional and surely I am expected to cope.

I now realise that what happened to me was a combination of physically being in an unsafe environment, but more importantly my internal sense of safety had shifted as a result of being at the shop. I have asked myself numerous questions in order to make sense of my experience: was it the area, was it the story, was it the incident, was I stressed, and what was the point of onset of my reactions? I discounted all of the above except the last question. I have worked in townships throughout my career, I was feeling fine and relaxed, I have heard clients tell stories of a similar nature at least a hundred times and, finally, dealing with survivors of armed robberies was part of my daily work.

Furthermore, for me trauma counselling has never been about the offence, but rather about assisting the survivors with their healing. The fulfilment in trauma counselling has always been seeing over and over that people can survive and more importantly experience emotional growth despite having experienced the most horrific events.

The onset of my reactions occurred when the manager told me about his experience and, on reflection, it is clear to me that the group did not evoke these feelings. I was already in a spiral 
which just worsened as the group progressed. Once more I realise that it was not the content of his narrative that opened Pandora's Box for me, but it was something in our unconscious interaction which set me off. I considered two possibilities: (1) I identified with him in some way; and (2) he symbolised something/someone for me.

Through discussion in supervision I have realised that both of the above possibilities were at play. I recognised that the manager symbolised someone whom I care about and whom I see as constantly living in a hostile environment.

For me the manager seemed to be such a sensitive and harmless person and I remember wondering how could this man survive in this environment. I also realised that perhaps I was feeling the fear that the manager did not allow himself to feel and that I had somehow tuned into this. I found that the theory around intersubjectivity, transference and counter-transference aided my understanding of what occurred to me that day.

\section{THE INTERSUBJECTIVE APPROACH TO COUNSELLING}

Stolorow, Brandchaft and Atwood (1987) introduced the term intersubjectivity into psychoanalysis. They began to examine intersubjectivity during a study of the interplay of transference and counter-transference in psychoanalytic therapy. In this study they looked at the fact that therapist and client come from different worlds and the impact that this had on therapy. This approach argues that therapy is mainly shaped by what the client brings to it; however, the subjective worlds of both therapist and client impact on the process. A basic assumption in psychoanalysis has been the concept of an "objective reality" that is known by the therapist and eventually by the client. The intersubjective approach argues that the only reality in therapy "is the subjective reality, i.e. that of the client, that of the therapist and the interplay of the two" (Stolorow et al., 1987:4).

This reality becomes evident as a result of empathic resonance, i.e. the client's unconscious issues becomes conscious through an intersubjective dialogue to which the therapist contributes his or her empathic understanding. This approach maintains that the therapist and client form a system (Stolorow et al., 1987).

I had never consciously thought about the person whom I care about and his hostile environment, but clearly it had been an issue for me. Meeting the manager and both our conscious and unconscious interaction raised my awareness of this.

\section{COUNTER-TRANSFERENCE}

The understanding of counter-transference has changed over the years in that it was previously seen as the therapist's feelings toward the client based on the therapist's own unresolved issues. The concept has been expanded on and it is now viewed as an interpersonal process between therapist and client, and as having an informative aspect. Thus counter-transference is seen as the complete emotional reaction of the therapist to the treatment situation, i.e. both the therapist's own issues as well as the therapist responding to the transference and communications of the client make up counter-transference. Projective identification, a concept developed by Melanie Klein in 1946, is a central concept in counter-transference. British and American analysts seem to understand the term differently. American analysts argue that there is an interpersonal aspect to projective identification and that the therapist's own unresolved issues will influence how the projection is perceived. The literature consistently reinforces that the therapist has a duty to reflect on who is feeling what and why they are feeling it within the 
therapeutic relationship (Casement, 1990; Corey, 1996; Gabbard, 1999; Grey, 1994; Horner, 1991; Maroda, 1991; Teyber, 1992).

Projective identification was clearly at play that day and, thinking about it later, I could understand why the manager could not, and possibly still cannot, allow himself to feel his terror. The reality is that he has to work in a dangerous situation on a daily basis and he needs to be able to function despite what he is feeling. His denial is serving a very important purpose.

I also found Giarratano's work (2004) on vicarious trauma very helpful in understanding my experience, especially her statement that vicarious traumatisation can happen very suddenly. her explanation as to why one can feel the way clients do also clarified the event for me and I think the last reason that she mentions, i.e. that symptoms can be evoked when the client's narrative is similar to a distressing issue in our lives or an unresolved issue from our past, ties in with the above discussion on counter-transference.

\section{CONCLUSION}

Writing this paper has been a very difficult process, because it brought all the emotions back and again I thought of the clients who come to The Trauma Centre and who have to retell their stories. Previously I would normalise clients' anxiety about retelling the story, but I now realise how cavalier I have been about the process. I had always thought that in order for me to help them, I needed to know what happened. I am humbled by the strength and resilience of our clients, who not only have to relive the horror but also have to do it publicly with a stranger.

I have asked myself certain questions as a result of this experience; these questions include: how often do we stop to think about the impact that our work is having on us; as social workers we work with clients' deepest wounds but what do we about own and how do we take care of ourselves? The value of supervision was once again highlighted for me in dealing with this experience.

I realise that I can see this experience as a sign to take a break from working with trauma or I can see it as a gift, albeit wrapped in terrible paper. The gift has been that this experience has shaken me into understanding my clients in a completely different way and it has also made me look at myself in a different light. I have learned that I can only be kind to others if I can be kind to myself. It is a pity that the staff of the shop will never know the gift that they have given me, but I feel that for me it is enough to salute their courage and to silently thank them for putting me in touch with my own.

\section{REFERENCES}

APPELT, I. 2003. Report on models of practice and research for the Trauma Centre for Survivors of Violence and Torture. The Trauma Centre, Cape Town. (Unpublished Paper)

BASS, E. \& DAVIS, L. 2002. The courage to heal. A guide for women survivors child sexual abuse. London: Vermillion.

CASEMENT, P. 1990. Further learning from the patient. The analytic space and process. London: Routledge.

COREY, G. 1996. Theory and practice of counselling and psychotherapy $\left(5^{\text {th }}\right.$ ed $)$. Pacific Grove: Brooks/Cole.

CROSSLEY, M.L. 2000. Introducing narrative psychology. Trauma and the construction of meaning. Buckingham: Open University Press. 
402

DSM (Diagnostic and Statistical Manual of Mental Disorders). 1994. (4 ${ }^{\text {th }}$ ed). Washington: American Psychiatric Association: 427-429.

GABBARD, G.O. (ed) 1999. Countertransference issues in psychiatric treatment. Washington: American Psychiatric Press Inc.

GIARRATANO, L. 2004. Clinical skills for managing acute psychological trauma. effective early intervention for treating acute stress disorder. Mascot: Talomin Books Pty Ltd.

GREY, A. 1994. An introduction to the therapeutic frame. London: Routledge.

HAJIYIANNIS, H. \& ROBERTSON, M. 1999. Counsellors' appraisals of the Wits Trauma Counselling Model: strengths and limitations, January (1-13) (Paper presented at a conference). Available: http://csvr.org.za/papers/paphh\&mr.htm. [Retrieved: 18/03/2002].

HORNER, A.J. 1991. Psychoanalytic object relations therapy. New York: Jason Aronson Press.

MARODA, K.J. 1991. The power of countertransference. Innovations in analytic technique. Chichester: John Wiley \& Sons Ltd.

McCANN, I.L. \& PEARLMAN, L.A. 1989. Vicarious traumatisation: a framework for understanding the psychological effects of working with victims. In: HOROWITZ, M. (ed) Essential papers on posttraumatic stress disorder. New York: New York University Press.

MITCHELL, J.T. \& EVERLY, G.S. 1997. Critical stress debriefing. An operation manual for the prevention of traumatic stress among emergency services and disaster workers. Elliot City: Chevron Publishing Co.

RAPHAEL, B. \& MELDRUM, L. 1995. Does debriefing after psychological trauma work? British Medical Journal, 310(6993):1479-1481.

RYNEARSON, E.K. 2001. Retelling violent death. Philadelphia: Brunner-Routledge.

SAAKVITNE, K.W. \& PEARLMAN, L.A. 1996. Transforming the pain. New York: Library of Congress Cataloguing-in-Publication Data.

SCRIGNAR, C.B. 1996. Post traumatic stress disorder. Diagnosis, treatment and legal issues. New Orleans: Bruno Press.

STACEY, M. 1999. What do we do when we do debriefing? The Trauma Centre: Cape Town, South Africa. (Unpublished Paper)

STOLOROW, R.D., BRANDCHAFT, B. \& ATWOOD, G.E. 1987. Psychoanalytic treatment: an intersubjective approach. London: Analytic Press.

TEYBER, E. 1992. Interpersonal process in psychotherapy. A guide for clinical training ( $2^{\text {nd }}$ ed). Pacific Grove: Brooks/Cole.

Ms Fatima Williams is a teaching assistant in the Department of Social Development at the University of Cape Town, Cape Town, South Africa. 